\title{
Implikasi Hermeneutik Al Qur'an dalam Epistemologi Islam
}

\author{
Lailatul Maskhuroh \\ STIT Al-Urwatul Wutsqo Jombang \\ lela.jombang@gmail.com
}

\begin{abstract}
:
Hermeneutics one of the philosophical disciplines of language, began to sound its resonance in 1998 which was first introduced by Hasan Hanafi. The pros and cons of this science still resonate with its loyal followers, and vice versa. There are professors of Islamic universities who have not recognized this knowledge from the beginning, but have not dampened the development of this science itself. So that there are those who equate hermeneutic science such as the science of interpretation and takwil. In Indonesia Aksin wijaya, Sahiron Syamsuddin, Muqsith Ghazali are lecturers who are persistent in developing this hermeneutic theory which is still productive until now. Hermeneutics is needed to understand the Koran, especially to answer contemporary problems oriented to human values that have not yet been resolved in classical interpretations according to Sayyid Husein Nasr. This is one of the reasons for accepting hermeneutics. There are also those who reject it and some are moderate, for example M. Quraish shihab.
\end{abstract}

Keyword: hermeneutics, human values, contemporary problems

\section{Pendahuluan}

Sebuah metode pendekatan yang dianggap barang baru di dunia timur (Islam) dalam mengkaji al Qur an, hermeneutic memiliki momennya untuk di bahas ulang di dunia akademis meskipun sampai sekarang belum ada hasil yang utuh dan komprehensif tentang ilmu ini dalam menafsirkan al Quran. Kebekuan dan kebakuan yang selama ini dalam memamahi al Qur'andianggap perlu penyegaran pemahaman dalam memahami ulang isi al Qur'an dengan metode Hermeneutic atas al Qur'an menjadi sebuah keniscayaan.

Teori hermeneutic masing-masing tokoh sangat beragam, salah satu contoh Fazlur rahman dengan teori double movement, hasan hanafi dengan kiri Islam dan Nasr Hamid abu zayd hermenetik humanism nya dan lain-lain telah menghasilkan bentuk tafsiran yang sangat berani dalam memahami al Quran. Begitu juga dengan ketiga tokoh Aksin Wijaya, Sahiron Syamsuddin dan Muqsith Ghazali yang masih produktif epistemologi hermeneutik mereka sampai sekarang. 
Hermeneutika adalah salah satu seni atau ilmu menafsirkan teks. ${ }^{1}$ tujuannya dimaksudkan untuk memperoleh kesimpulan teks. Hermeneutic selalu berhubungan dengan 3 aspek 1). Dalam konteks apa teks ditulis 2). Bagaimana komposisi tata bahasa teks (ayat) tersebut 3). Bagaimana keseluruhan teks (ayat), weltanchauungnya atau pandangan hidupnya. ${ }^{2}$

Urgensi hermeneutik dalam atas al Quran masih diperdebatkan. Pro dan kontra terhadap ilmu ini hingga sekarang masih terdengar sebagai ilmu yang debatable dalam kajian keislaman ${ }^{3}$. Di Indonesia, Adian Husaini, menolak hermeneutika secara mutlak, M. Quraish shihab berbeda pendapat bahwa sebagian teori dan metode hermeneutika dapat digunakan dalam memahami pesan al Quran. Di Mesir, Hassan hanafi berpendapat mungkin saja penerapan hermeneutika dalam teks-teks keagamaan. Muhammad Imarah menentang penerapan hermeneutika.

Masing-masing yang pro dan kontra membangun argumentasi. Yudi Wahyudi menjelaskan kelompok asal muasal hermeneutika bagi kelompok yang menolaknya, mereka berpendapat: Dengan mengakui hermeneutic atas al Quran, berarti mengakui ketidak autentikan al Qur'an. Karena di Barat Hermes adalah dewa yang bertugas menafsirkan pikiran Tuhan dan secara otomatis pesan Verbatim tuhan hilang karena bercampur dengan pemikiran Hermes. ${ }^{4}$

Dari wacana di ketahui bahwa golongan yang menolak hermeneutic atas al Quran adalah ketika memposisikan al-Quran bukan otentik firman Allah, tetapi ketika hermeneutic dipakai untuk mencari makna yang lebih dalam dari teks alQur;an maka tidak masalah. Pandangan ini di anut oleh Hasan Hanafi dan Yudian wahyudi yang disebutnya "Hermeneutik yang bersifat horizontal, yaitu menafsirkan al quran setelah wahyu ilahi dicatat secara verbatim. ${ }^{5} \mathrm{Nada}$ negative juga di suarakan oleh M. 'Imarah' ${ }^{6}$ karena menyamakan hermeneutika berarti mendekontruksi teks. Padahal itu hanya salah satu makna dari hermeneutic. M. Quraish shihab, seorang mufasir Indonesia, bersifat moderat dalam menyikapi

\footnotetext{
1 Amina Wadud Muhsin, Quran and Woman, dalam Charles Kurzman, liberal Islam, 128. Bandingkan dengan Fazlur Rahman, Major Themes of The Qur;an (Chicago : Bibliotecha Islamica, 1980) terutama bagian mukadimah.

2 ibid

${ }^{3}$ Lihat Felix Komer, Alter Text neur context: Koranhermeneutic in der Turkei heute (Freiburg : herder, 2006) : Yudian Wahyudi, Ushul Figh versus Hermeneutika : membaca Islam dari Kanada dan Amerika (Yogyakarta: Pesantren Nawesea Press, 2006), Hasan Hanafi, Hermeneutikaal Qurqn, terj. Yudian Wahyudi (Yogyakarta : Nawesea Press, 2009)

4 Yudian Wahyudi, Ushul Figh versus Hermeneutika : membaca Islam dari Kanada dan Amerika (Yogyakarta: Pesantren Nawesea Press, 2006), 7.

5 Wahyudi, Ushul Fiqh versus Hermeneutika, 7.

${ }^{6}$ M.'Imarah "Hadza huwa al Islam: Qiraat al-Nash al Dini baina al Ta'wil al Gharbi wa al-Ta'wil al Islami (Kairo : maktabahal-Syuruq al Dualiyyah, 2006)
} 
hermeneutic dan bersikap kritis dalam paoin-poin tertentu. Ini merupakan sikapnya yang obyektif terhadap hermeneutic. ${ }^{7}$

Zaman terus berubah menawarkan berbagai pendekatan dalam upaya mencari pembumian ayat-ayat ilahi. Begitu juga dalam memahami agama, pendekatan hermeneutic merupakan pendekatan yang tugas pokoknya menafsirkan teks klasik/teks asing laksana milik zaman kita dan tempat serta kultur berbeda. ${ }^{8}$

Mekanisme kerja hermeneutic adalah terletak pada pembacaan teks apakah menghendaki makna subjektif ataukah makna objektif. Dalam hal ini ada 3 bentuk hubungan hermeneutic hubungan penggagas dengan teks, hubungan pembaca dengan penggagas, dan hubungan pembaca dengan teks ${ }^{9}$ atau dengan kata lain hermeneutic menekankan aspek kebahasaan di mana antara teks, pengagas dan pembaca membangun pemahaman atas kesepakatannya sendiri.

\section{Pembahasan.}

\section{Konsep Hermeneutic}

Hermeneutic berasal dari kata Yunani yang berarti dewa hermes (dewa yang bertugas menafsirkan firman Tuhan). Istilah Hermeneutic yang mulai mencuat pada zaman kontemporer ini pertama kali di kenalkan oleh hasan hanafi, meskipun sayd Husein Nasr menyebut dirinyalah yang memperkenalkan istilah tersebut pertama kali.

Hermeneutic dengan segala problematikanya, yang di sinyalir agenda Barat untuk menjajah orang Islam selain food, fashion, free sex adalah thougt yang di istilahkan oleh Naisbitt, lambat laun mulai di nikmati oleh para sarjana muslim yang di anggap "mainan baru" dan mampu membongkar al Qur'an dengan seobjektif mungkin atau melemparkan pendapat para ulama yang selama ini yang telah mapan dengan segala kualifikasi keilmuan di pojok penuh keraguan di satu sisi.

Hermeneutic adalah sesuatu yang sangat berbeda dengan tafsir. Bila tafsir sudah mendasarkan bahwa terdapat kebenaran yang pasti sedangkan hermeutik mengakui kebenaran bersifata relative dan tentative. Hermeneutic menghendaki komunikasi yang tiada berujung (blunder), tafsir dengan para

\footnotetext{
7 Nasr Hamid Abu Zayd tampak berada pada posisi ketiga ini, namun menurut muridnya yang pernah dekat dengannya, Nur Ikhwan, Abu belum pernah beranjak dari aturan baku Gadamer (hermeneutic subjektif), meskipun cirri yang lain bisa ke hermeneutic pembebasan. Lihat Nur Ikhwan" al Quran sebagai teks Hermeneutik abu Zaid" dalam Abd Mustaqim (ed), Studi al Quran Kontemporer, (Yogya :Tiara Wacana, 2002), 163

${ }^{8}$ Komarudin Hidayat, Memahami Bahasa Agama, Sebuah Kajian Hermeneutik (Jakarta : Paramadina, 1996), 17

${ }^{9}$ Moh. Nur Ichwan, “Teori Teks dalam Hermeneutika”, 27-40
} 
ulama meyakini ada kebenaran yang pasti dalam al Quran. Ini salah satu alasan pendapat yang pro dan yang kontra.

Adapun kelompok yang menerima hermeneutic atas al Quran bahkan cenderung mengkritik para penafsir, mereka memberi masukan terhadap kajian tafsir yang selama ini sudah ada, pertama struktur penalaran yang cenderung dogmatis tanpa penjelasan logis, misalnya kenapa harus melaui tahapan tersebut, dst. Kedua dalam tradisi keilmuan Islam, tafsir bi al ma'tsur dianggap paling baik dan dianggap paling selamat imannya, ini menyebabkan tafsir tidak up to date dalam menjawab problem kekinian bahkan cenderung tertinggal. Ketiga Tafsir masih bersifat teoritis dan teosentris dan belum banyak jadi problem solving masalah-masalah soasial, kemanusian, ketertindasan, kemoderenan . Al quran belum mampu menjadi rahmah (membawa perubahan dan kebaikan), bukan hanya sebagai hudan (petunjuk teoritis setelah di pelajari) dan syifa; (obat di baca dengan cara amalan wirid).

Sedangkan kelompok yang berpendapat bahwa hermeneutic tidak bisa di berlakukan atas al Qur'an, karena beberapa alasan yaitu hermeneutic tidak lahir dari ruang hampa, ia lahir di dunia Barat yang merupakan produk masyarakat yang punya pandangan dan peradaban sendiri. Pendapat ini di pegang oleh mayoritas mufasir dan cendekiawan muslim. Ini di perkuat dengan pendapat seorang pakar heremeneutik Werner G. Jeanrond,ada 3 milieu yang menjadi sebab lahirnya hermeneutic menjadi sebuah teori, konsep intrepretasi. Pertama Yunani menjadi basic penafsiran mereka, kedua kitab suci mereka yang bermasalah (Yahudi dan Nasrani), ketiga eropa pada zaman enlightenment yang berusaha membawa hermeneutic keluar dari konteks keagamaan. ${ }^{10}$ Selain itu epistemology Islam dan Barat berbeda, di dalam islam sumber epistemology bukan Cuma akal tetapi juga Al-Quran sebagai sumber tak terbantahkan, di Barat akal sebagai satu-satunya sumber kebenaran.

Aliran hermeneutik ada 3. Pertama hermeneutic objektif. Tokoh-tokohnya Friedric Schelermacher (1768-1834), Wilhelm Dilthey(1833-1911) dan Emilio Betti (1890-1968) yang merupakan tokoh pengembang di era klasik ${ }^{11}$. Hermeneutic adalah ungkapan jiwa pengarangnya, karena memahami teks adalah penafsiran teks sebagaimana yang dipahami pengarangnya. Yang di sebut makna bukan kesimpulan kita tetapi yang bersifat instruktif. ${ }^{12 k e d u a ~}$

${ }^{10}$ G Jeanrond Werner, Theological Hermeneutic, Developmenand significance, Macmillan, London, $12-$ 13.

${ }^{11}$ Fazlur Rahman, Islam dan Modernitas, terj. Ahsin Muhammad( Bandung, Pustaka, 1985), Rahman memasukkan juga emillo Betti dalam tradisi hermeneutika objektif ini.

12 Joseph Bleicher, Contemporary Hermeneutic (London, Routlege \& Kegan Paul, 1980), 29. Referensi lain lihat Nasr Hamid Abu Zaid, Isykaliyat al ta;wil wa aliyat al Qira;ah, (Kairo : al Markaz al Tsaqafi, tt), 11, Sumaryono, Hermeneutic, (Yogya, kanisius, 1996), 31 
hermeneutik subjektif. Tokohnya Hans-Georg Gadamer (1900-2002) dan Jacques Gerrida (L. 1930)13. Hermeneutic model ini adalah memahami apa yang ada di teks. Dan isi teks bukan dari ide awal penulis' ${ }^{14}$. Ketiga Hermeneutik pembebasan, yaitu hermeneutic yang di dasarkan pada hermeneutic subjektik tetapi juga aksi. Tokoh-tokoh aliran ini adalah Hassan Hanafi (L.1935), Farid Esack (1959)

\section{Hubungan Hermeneutik dengan al Quran}

Studi keislaman yang hadir dalam paket produk ulama abad pertengahan yang disentegratik dan dianggap final dan melahirkan taqdis al afkar al dini (pensakralan produk-produk pemikiran keagamaan) karena kajiannya minus dari analisis historis-sosiologis-hermeneutik terhadap Islam, akibatnya pemahaman terhadap al Quran bisa tereduksi ataupun terputus dari konteks dan relevansi historisnya ${ }^{15}$.

Hermeneutik metodologi yang di adopsi dari Barat belum semua menerima. Pemaknaan hermeneutic secara verbal dari istilah inggris hermeutics dan verba latin interpretari untuk menganalisis definisi yang di inginkan serta untuk tau letak perbedaaan etimologis antara hermeneuin dan exegeisthai untuk menyajikan perbedaan hermeneutic dan exegesis (penafsiran). ${ }^{16}$

Pemahaman umat Islam selain yang memandang bahwa tafsir adalah al Quran itu sendiri ${ }^{17}$, sejarah umat Islam juga terjadi banyak kontradiksi dan konflik. Banyak sekte dan mazhab, ijtihad dan pentakwilan. Kenyataan ini tidak menghalangi "nalar arab" untuk mengkaji persoalan yang mempersatukan keduanya. Iman adalah kebenaran. Nalar harus mempunyai kebenaran nalar teologis sebagai kebenaran manusia. Filsuf Arab selain menempuh metode penelitian hal ihwal wujud berdasarkan tradisi Yunani, mereka juga mengamati perintah kenabian dan wahyu yang merupakan sumber kepercayaan, landasan agama dan acuan makna. ${ }^{18}$

Bahasa adalah cara kita berpikir, berbicara dan menulis. Hermeneutic berhubungan dengan bahasa. Dengan bahasa kita mengerti dan membuat interpretasi. Hermeneutik mengalami pergeseran dari sekedar pengantar penafsiran menjadi metodologi penafsiran. Dalam teologi problem hermeneutic adalah bagimana cara memahami realitas yang di kandung teks suci injil serta menerjemahkan dalam teks yang dapat di pahami manusia modern.

\footnotetext{
13 Fazlur Rahman, Islam dan Modernitas, 13

14 K. Bertenz, Filsafat Barat abad XX, I (Jakarta , Gramedia, 1981),225

${ }^{15}$ M. Rizka Chamami, Studi Islam Kontemporer, (Semarang: Pustaka Rizki Putra, 2002), 133

${ }^{16}$ Muhammad 'Ata al Sid, Sejarah Kalam Tuhan, (Jakarta : Teraju PT. Mizan Publika, 2004,), 8

17 Opcit, 134

18 Ali Harb, Hermeneutic Kebenaran, (Yogyakarta : Lkis, 2003), 126-127.
} 
Hermeneutic menyelidiki hakikat pemahaman dan bagaimana pemahaman tersebut terjadi. ${ }^{19}$

Bahasa symbol juga di pakai dalm kitab suci dan ini bahasa yang terbaik karena memiliki maksud yang lebih besar dibanding bahasa yang sudah jelas maksudnya. Bahasa symbol lebih susah di pahami dan tidak mempunyai kejelasan arti serta tujuan pendidikan lebih susah tersampaikan. ${ }^{20}$

\section{Hermeneutika dan Tafsir Al Quran}

Hermeneutika adalah ilmu yang membahas tentang penafsiran (theory of interpretation) dan bermkana interpreting dan understanding dalam memahami sebuah teks ${ }^{21}$. Objek kajiannya meliputi interpretasi terhadap teks-teks, hukum, filsafat, social, sejarah, politik dan bahkan terhadap teks-teks keagamaan dalam bidang kajian Quranic studies dalam studi keislaman kontemporer. Secara umum hermeneutika dapat diartikan sebagai teori interpretasi atau alat analisis untuk mengkaji sebuah teks.

Dalam Konferensi International Kedua tentang Pendidikan Islam di Islamabad, Al-Attas menekankan bahwa ilmu pertama di kalangan Muslim, yakni Ilmu Tafsir, tetap sangat berharga dan bisa diaktualisasikan, sebab adanya karakteristik ilmiah dari bahasa Arab. Tafsir tidaklah identik dengan hermeneutika Yunani atau hermeneutika Kristen atau metode interpretasi kitab suci dari budaya atau agama apa pun dan hermeneutic bukanlah tafsir 22

\section{Pergeseran Paradigma Tafsir : dari Teosentris-Eskatologis ke Antroposentris-} Transformatif.

Tafsir yang merupakan produk usaha ulama dalam memahami al Quran mengalami pergeseran, bila dilihat dari perspektif Kuhnian ${ }^{23}$, karena al Quran

${ }^{19}$ Muhammad Ata al Sid, Sejarah kalam Tuhan, (Jakarta : Teraju PT. Mizan Publika, 2004),9

${ }^{20}$ Syamsuddin Abdullah dan harits Abdul Salam dkk, Fenomenologi Agama (Jakarta : tp, 1983-1984), 109.

${ }^{21}$ Josef Bleicher, Contemporary Hermeneutic (London : Routledge and Paul Keangan, 1980), 1-5 dan Mudji Raharjo "Dasar-dasar Hermeneutika anatar Intensionalisme dan Gadamerian (Yogyakarta : ar-Ruzz Media, 1998), 29

22 Wan Mohd Nor, The Educational Philosophy and Practice of Syed Muhammad Naquib al-Attas: An Exposition of the Original Concept of Islamization, 1998: 343-344) Lihat, artikel Wan Mohd Nor Wan Daud di Majalah Islamia edisi 1, tahun 2004 dan wawancaranya di majalah yang sama pada edisi 2, tahun 2004).

${ }^{23}$ Menurut Kuhn, ilmu pengetahuan dalam waktu tertentu akan di dominasi oleh paradigm tertentu. Pada saat itu ilmu pengetahuan berjalan normal, suatu periode akumulasi pengetahuan di mana para ilmuan bekerja dan mengembangkan paradigm yang sedang berpengaruh. Lama kelamaan seiring adanya perubahan, para ilmuawan pun dengan pertentangan teori lama dan kenyataan akhirnya terjadi krisis. Paradigm lama di pertanyakan kevaliditasannya. Revolusi tidak bisa di hindari maka terjadi perubahan besar dalam dunia keilmuan besar pada periode revolusi tersebut. George Ritzer, Sosiologi Pengetahuan Berparadigma Ganda, ter. Alimandan (Jakarta : Rajawali Press, 2004),5 lihat Thomas S. Kuhn, The structure of Scientific Revolutions : Peran Paradigma dalam Revolusi Sains (Bandung : Remaja Rosdakarya, 2002). 
shalikhun likulli zaman wa makan. Agama tergantung harapan penganutnya yang mendorong untuk mencari solusi dari agamanya. Pemahaman keagamaan pada masing-masing ranah ruang dan waktu bergantung pada persoalan yang dihadapi umat. ${ }^{24}$

Pada masa awal Islam yang di hadapi umat Islam adalah persoalan ketuhanan dan kehidupan setelah mati lahirlah corak keagamaan teosentriseskatologis. Setelah itu realitas berubah yang menjadi persoalan kemanusiaan, keadilan, kesetaraan, dst akhirnya memunculkan paham keagamaan antroposentris-transformatif. 25

Era teosentris-eskatologis menguasai paradigma Islam dalam waktu yang begitu panjang dan kajian al Quran memusatkan pada Tuhan, membela Tuhan. Era ini di sebut era formasi nalar mitis ${ }^{26}$. Manusia mengabdi sepenuhnya pada Tuhan dan kata transendensi Tuhan menjadi sangat popular di kalangan ini. Sangat mengesampingkan peranan akal dalam menggali pesan pesan tuhan, Nabi pemegang otoritas sepenuhnya wahyu Tuhan.

Era formatif teologis yaitu era setelah era nalar mitis, di mana aliran, madzhab dan organisasi keagamaan memegang otoritas dalam memahami agama, tafsir tidak bersifat teologis demi membela Tuhan sebagaimana era formatif. Model tafsir yang muncul era ini bersifat ideologis. ${ }^{27}$ Tafsir di gunakan untuk Mu'tazilah menafsiri al Qur'an untuk mendukung alirannya, begitu juga ahl sunnah wal Jamaah dan Syi'ah.

Muhammad Abduh hadir sebagi penggugat kedua kedua nalar tafsir yang sudah ada (nalar mitis dan nalar teologis). Karena kedua tafsir tersebut membawa umat Islam dalam kondisi makin terbelakang, meskipun berbeda tetapi tujuan kedua tafsir tersebut sama yaitu membela Tuhan (Theo Sentris). Muhammad abduh meanwarkan nalar rasional dalam memahami tafsirnya ${ }^{28}$.

${ }^{24}$ Hasan Hanafi, Al Din wa al-Tashwirah fi Mishr, 1952-1981, al Yamin wa al Yasar fi al Fikr al Dini (Kairo : Maktabah madhbuli, 1989). 103

25 Aksin Wijaya, Paradigma baru Wacana Agama: Melepaskan Agama dari Bayang-Bayang Lembaga, Organisasi dan Aliran Keagamaan", Millah : Jurnal Studi Agama, Pascasarjana UII, vol 7, no 2 (Februari 2008), 1-22

${ }^{26}$ Abdul Mustaqim, Pergeseran Epistemologi Tafsir, (Yogyakarta : Pustaka Pelajar, 2008), 34-40

27 Tafsir ideology adalah tafsir yang lahir dari kelompok ideologi tertentu dan digunakan untuk menjustifikasi ideologinya, seperti tafsir Sunni, Syi'ah dan sebagainya. Masdar F. Mas'udi, "Paradigma dan Metodologi Tafsir Emansipatoris" dalam Islam Emansipatoris : Menafsirkan Agama untuk Praksis Pembebasan, ed. Very Verdiansyah, (Jakarta : P3M, 2004), ix-xiv, bandingkan dengan Very Verdiansyah Islam Emansipatoris : Menafsirkan Agama untuk Praksis Pembebasan (Jakarta : P3M, 2004), 63, Mustaqim, Pergeseran....., 72-111

${ }^{28}$ Ignaz Golziher mencatat ada 5 kecenderungan tafsir atau studi al Quran mulai era klasik sampai era modern yakni studi al Quran tradisional, studi al Quran dogmatis, studi al Quran mistik, studi al Quran sectarian dan studi al Qur an modern. Studi al Quran modern ignaz golziher mengaitkan dengan pemikiran yang berkembang di India (Akhmad Khan sebagai figurnya) dan 
Masalah modern yang di hadapi sekarang adalah persoalan kemanusiaan seperti hak asasi manusia, kemiskinan, keadilan, kesetaraan dll. Dengan dasar ini manusia modern mencari format baru tafsir untuk membela kepentingan mereka. ${ }^{29}$ ini bertolak dari paradigm kritis. ${ }^{30}$ dengan paradigma ini bertujuan menguak kepentingan ideologis dibalik teks, baik teks tertafsir maupun teks primer (mushaf usmani) dan mencari makna al Qur an yang "berarti" 31 untuk manusia sekarang. Dan hermeneutic yang bisa menggali "makna yang berarti" ini.

\section{Hermeneutik Mitra tafsir?}

Tafsir mampu mengungkap membantu manusia dalam memahami makna al Quran. Memahami dari satu sudut tertentu. Ketika tafsir sudah "menteologi" menjadikan al Quran menjadi sempit dan lain waktu memperlebar ke arah wilayah yang tak terfikirkan. ${ }^{32}$ Ijtihad juga sangat di anjurkan oleh Nabi Muhammad SAW jika 'secara harfiah' tidak terdapat dalam al Quran, bahkan Allah memberi pahala satu bagi yang ijtihadnya salah dan berpahala dua bagi yang benar hasil ijtihad. Sejalan dengan anjuran nabi tersebut Ali bin Abi thalib menyatakan "Al Qur'an bayn daftai al mushhaf la yanthiq, innama yanthiq (yatakallam ) bih al-rijal". Kekayaan al Quran tidak akan habis di gali. Al Quran benda mati. Manusialah yang bertugas menghidupkan teks (al Qur an) dengan takwil dan hermeneutika. Hermeneutic inilah yang dimaksud pembacaan manusiawi terhadap agama ${ }^{33}$.

Mesir (Muhammad Abduh tokohnya). Ignaz Golziher, Madzahib al Tafsir al Islami (Beirut : Dar Iqra, 1983), 352-92. Abduh menawarkan penggunaan akal dalam menafsirkan al Quran akhirnya bermunculan beberapa model tafsir : tafsir ilmiah, tafsir relais, tafsir sastra.J.J.Jansen, Diskursus Tafsir al Quran Modern, ter. Hairussalim (Yogyakarta : Tiara Wacana, 1997)

29 Jalaluddin Rahmat, Islam dan Pluralisme : Akhlak Qur an menyikapi Perbedaan (Jakarta : Serambi, 2006), 118-39, Aksin Wijaya, Menusantarakan Islam : Menelusuri Jejak Pergumulan Islam yang Tak Kunjung Usai di Nusantara (Ponorogo : STAIN Ponorogo Press, 2011), 231-73

30 Paradigma kritis merupakan perpaduan paradigma pluralis dan konflik. Paradigm kritis selalu mempertanyakan setiap kemapanan yang ada dan selalu curiga terhadap kesadarn umum da rasionalitas yang terselubung. Ini suatu hal yang wajar di lakukan oleh paradigm kritis, karena pemegang otoritas sudah biasa menciptakan hegemoni. Yang tidak wajar jika otokritik juga di arahkan pada realitas internal struktur wacana pemikirannya sendiri dan ini di alami para pencetus paradigm kritis. Wijaya, Paradigma...,102; Abdul mustaqim, Pergeseran.. 72-111

31 "makna berarti" dari hermeneutic filosofis Hans Gadamer. Sahiron Syamsudin, "Integrasi Hermeneutika George Hans gadamer ke dalam ilmu Tafsir? Sebuah Proyek Pengembangan Metode pembacaan Al Quran pada masa Kontemporer" makalah dalam Annual Conference Kajian Islam oleh Dipertais Depag RI di bandung tanggal 26-30 November 2006; Nur kholis Setiawan , Akar-akar Pemikiran Progresif dalam Kajian al Quran (Yogyakarta : Elsaq, 2008), 67-73.

32 Muhammad Arkoun, The Unthought in Contemporary Islamic Thought (London : Saqi Books, 2002), 11-36.

${ }^{33}$ Muhammad Mujtahid al Syibtsari, Qiraah Basyariayyah li al-Din, ter. Ahmad al Qbanji, (Beirut : alIntisyar al Arabi), 11,102-6. 
Tafsir dan takwil sudah di kenal sejak ulama dahulu sebagai teori yang sakral yang berasal dari Allah. Hermeneutik yang di nilai teori profan yang di gunakan untuk "pembacaan manusiawi" ke dalam studi agama, khususnya Islam, menuai masalah. Muncul masalah bila takwil yang mendapat dukungan al Qur'an bisa tersingkir oleh teologisasi tafsir ${ }^{34}$, apalagi hermeneutika ${ }^{35}$.

Tafsir bukanlah al Quran . Legistimasi al Quran terhadap takwil lebih besar dari pada terhadap tafsir. Takwil tersingkir setelah menteologi dan menjadi "anak tiri" al Quran yang sebelumnya menjadi "anak kandung" tafsir. Hermeneutic yang tidak mendapat legistimasi al Quran pun prinsip semangatnya sama dalam menemukan pesan Tuhan dalam al Quran.

\section{Hermeneutic dan Tafsir al Quran : Antara Perbedaan dan Relevansi}

Hermeneutic berasal dari tradisi Yunani, kemudian berkembang menjadi metodologi bible, lalu oleh para teolog dan filosof Barat di kembangkan menjadi metode penafsiran secara umum dalam ilmu social dan humaniora. ${ }^{36}$ Kaum liberalis yang tentu tidak bebas nilai dan mengandung banyak asumsi dan konsekwensi sekarang banyak di kampanyekan.

Tafsir al Quran memiliki konsep yang jelas dalam islam. Fakta empiris menunjukkan beberapa mufassir zaman dahulu memiliki kesepakatankesepakatan sepanjang masa. Hermeneutic di bangun atas paham relativisme. Hermeneutic bila di sinonimkan dengan tafsir menggiring opini semua produk tafsir bersifat relative dan semua problem yang terjadi di hermeneutic juga terjadi di dalam al Quran. ${ }^{37}$

Bila hermeneutic di terapkan untuk menafsirkan al Quran, berakibat :1). Munculnya sifat kritis dan curiga terhadap al Quran, 2). Al Quran produk budaya Arab dan mengabaikan unsure transenden, 3). Munculnya relativisme tafsir, sehingga tafsir sulit di terapkan karena kebenarannya relative.

\section{Al-Quran Produk Pemikiran Manusia}

Nabi Muhammad SAW menerima al Quran di Gua Hira' dalam rangka kontemplasi terhadap kondisi masyarakat Arab yang kacau budayanya, kemaksiatan merajalela. Perilaku aniaya dan semua kemaksiatan terjadi di mana-mana. Dalam masa bertahhanus ini lah nabi Muhammad SAW di datangi oleh makhluk yang sangat kuat (jibril) dan disuruh membaca (iqro). Inilah titik awal tanda Muhammad terpilih sebagi manusia istimewa (Nabi) yang oleh Barat ini di anggap sebagai proses Muhammad membuat al Quran. ${ }^{38}$

\footnotetext{
34 Wijaya, arah..., 146-58.

${ }^{35}$ Masuknya gagasan dan metode ilmiah kedalam wacana penafsiran al Qur'an

${ }^{36}$ Adian Husaini dan Abdurrahman al Baghdadi, Hermeneutika dan Tafsir al Quran,8

37 Adnin Armas, Tafsir al Quran atau hermeneutika al Quran?, http/ / www.dewandakwah.com.

38 Ugi Suharto, "Apakah Al Quran memerlukan Hermeneutika" dalam Islamia, Tahun 1 no.1, $2004,52$.
} 
Ulama Islam menganggap ketika di Gua hira; Nabi mendapat bimbingan Allah dengan menerima al Quran sebagai petunjuk umat seluruh dunia sampai kiamat, sedangkan orang Barat menganggap al Quran hasil kontemplasi nabi Muhammad, produk budaya, produk berfikir yang harus dilihat sejarah dan konteksnya. Demgan dasar ini Barat menganggap al quran layak di tafsiri dengan hermeneutic. Ini adalah serangan eksternal Barat. Sedangkan dalam internal umat Islam sendiri melalui islam modernis, di antaranya Nasr Hamid Abu Zayd dan kontruksionis lainnya yang mengatakan bahwa alquran adalah produk muhammad membantah keyakinan umat islam selama ini bahwa al quran itu makna dan lafadz dari Allah SWT. ${ }^{39}$

\section{Kritik Ulama Terhadap Hermeneutika}

Sebaik-baik generasi adalah generasi sahabat, tabiin, tabiit tabiin, begitupun dalam memahami al Quran. Hal ini juga di dasarkan pada sebuah hadis shahih. yang artinya Nabi bersabda : "sebaik-baik manusia adalah generasiku (para sahabat) kemudian generasi sesudah mereka (tabiin) kemudian yang dating sesudah mereka (para pengikut tabiin).

Hermeneutik menganggap metodenya yang paling pas dalam menafsirkan al Quran, berlawanan dengan pendapat yang selama ini di maklumi orang Islam bahwa generasi awal Islam menempati posisi yang paling unggul, bahkan pengikut hermeneutic berpendapat bahwa kebenaran pendapat mereka perlu di uji lagi. ${ }^{40}$ dan ulama terdahulu pada tempat yang tidak lagi unggul. Pandangan di atas menimbulkan kekahawatiran ulama dalam bebrapa hal berikut ini :

a. Dekontruksi Epistemologi Ulama Terdahulu

Posisi al Quran begitu istimewa di hati umat Islam, sebagai firman Allah yang harus dijaga keasliannya. Ulama terdahulu menggunakan ilmu tafsir sebagai salah satu cara memahami al Quran, lebih dari itu ilmu tafsir dianggap sebagai kebenaran al Quran itu sendiri. Para ulama Keilmuan keseriusan semua di curahkan untuk menghasilakn sebuah karya tafsir yang sangat bernilai sekali. Untuk memahami alquran secara mendalam dan prakteknya lewat ilmu tafsir.

Teori social berbunyi bahwa adanya peradaban yang besar akan mengekspansi peradaban yang lebih kecil, bila terjadi penolakan maka akan terjadi konflik peradaban. ${ }^{41}$ Kebudayaan yang besar berpotensi menjadi patron untuk kebudayaan yang lebih kecil atau kebudayaan yang lebih kecil menjadi replica dari kebudayaan atau peradaban yang lebih besar. Bila di

\footnotetext{
39 Taufiq Adnan Amal, Rekonstruksi sejarah alQuran (Yogyakarta : FkBA), 334

40 Armas, Tafsir...

41 Samuel Huntington, Benturan Antar Peradaban, ter. M. Sadat Ismail (Yogyakarta : Bentang, 2000), 123.
} 
kaitkan dengan keberadaan hermeneutic berarti menggeser ilmu tafsir yang sudah sekian abad telah mapan di bangunan epistemology Islam di anggap runtuh dengan hadirnya hermeneutic bila hermeneutic di anggap kebenarannya dalam memahami al Quran. ${ }^{42}$

b. Dekontruksi Al-Quran

Jaringan Islam Liberal (JIL) secara historis memprtanyakan lagi keabsahan al Quran yang sekarang dan tentang kenabian Nabi Muhammad SAW. JIL berusaha membuat al Quran versi golongannya sendiri. Ini adalah upaya dekontruksi ilmu tafsir atas hermeneutic. Para pendukung hermeneutic menganjurkan al Quran harus bersifat local bukan universal seperti selama ini dan harus emansipatif.

Menjadikan hermeneutic sebagai ganti dari ilmu tafsir al Quran adalah dekontruksi bukan rekonstruksi. Para penganjur hermeneutic mengkritisi al Quran harus bersifat local, tidak universal. Selain itu al Quran juga tidak emansifatif, membelenggu sehingga perlu diperbarui. Al Quran yang beredar sekarang adalah hasil paksaan utsman bin Affan dan banyak ayat-ayat yang salah.43 Jaringan Islam Liberal (JIL) sedang berusaha membikin al-Quran versi JIL ${ }^{44}$ Nabi Muhammad pun harus di teliti sebagai manusia yang banyak kekurangan, tidak sebatas mitos yang di kagumi belaka. ${ }^{45}$ Menurut Taufiq Adnan Amal dalam tulisannya banyak menyebutkan tentang kekurangan al Quran misalnya Al Quran bahasa yang di pakai bahasa gado-gado karena tarik menarik antar penyusunnya waktu awal penyusunannya, ${ }^{46}$ dan seolah-olah memberi keyakinan bahwa naskahnaskah al Quran telah hilang dan tidak ada kesepakatan dalam penamaan 114 surat dan sejak kapan adanya nama-nama surat yang beragam. ${ }^{47}$ Pandangan-pandangan seperti ini mengagungkan al Quran atau sebaliknya.

c. Masuknya Teori Barat Ke Dalam Epistemologi Islam

Dengan menganggap benar hermeneutic al Quran maka hasil tafsir yang merupakan karya ulama-ulama terdahulu dianggap salah. Ini berimbas pada pemahaman al quran dan juga berimbas pada ilmu-ilmu lain. Hermeneutic merupakan upaya sistematis untuk menghancurkan Islam. Bila hermeneutic dianggap metode yang benar sedangkan yang berpegang pada tafsir adalah salah. Pertanyaan yang muncul kemudian,

\footnotetext{
42 Armas, Tafsir..., 46

43 Admin Armas, "Westernisasi dan Islamisasi Ilmu” dalam Islamia Tahun !! no. 6 Juli-September 2005,40

44 Majalah Syir'ah no.2 Tahun 2002

45 Kompas, 18 Nopember 2002.

46 Amal, Rekonstruksi..., 334

47 ibid
} 
akal siapa yang berhak dijadikan ukuran kebenaran dalam menafsirkan al Quran? Ulama 14 abad lalu yang paling shalihnya umat dalam memahami dan berpegang teguh pada sunnah Nabi Muhammad SAW atau tokohtokoh hermeneutic? ${ }^{48}$

Dalam Islam, dalam proses turunnya wahyu, Nabi Muhammad berperan pasif, hanya sebagai penyampai apa yang disampaikan kepadanya melalui malaikat jibril. ${ }^{49}$ Tidak mengapresiasi atau mengolah wahyu yang di terimanya, kemudian disampaikan kepada umatnya.

\section{KESIMPULAN}

Hermeneutic di terima sebagai solusi alternative untuk membaca ulang teks al Quran yang di anggap sudah tidak relevan lagi tafsir karya imam dahulu dengan kondisi kemanusiaan sekarang. Sikap para ulama berbeda dalam menanggapi metode hermeneutic karena berimbas, pertama mendekontruksi ulama salaf, kedua dekontruksi epistemology ulama terdahulu, ketiga masuknya nilai Barat ke dalam Epistemologi Islam, Ke empat tidak ada nilai yang absolute termasuk al Quran Kelima al quran produk manusia. Solusi dari adanya hermeneutic menempatkan ulama terdahulu dalam posisi mulia dan tidak mendekonstruksi epistemology Islam merupakan tawaran munculnya hermeneutic yang memposisikan mulia kedudukan ulama terdahulu merupakan solusi dari adanya hermeneutic yang sekarang. Tidak mendekontruksi bangunan epistemologi islam dan memposisikan al Quran sebagai kebenaran yang absolute.

Selain itu implikasi adanya hermeneutic yang bertentangan dengan ide tradisional ialah :

1. Tanpa konteks, teks tidak berharga dan bermakna sementara ide tradisional menyatakan bahwa yang tahu makna sebenarnya adalah Allah.

2. Manusia sebagai perantara pemberi makna, ide tradisional menyatakan bahwa Allah lah yang menganugerahkan pemahaman yang sempurna.

3. Ilmuwan muslim menyatakan maksud Al Quran hanya bisa dipahami dengan benar oleh Dzat yang menurunkan al Quran, tetap ada jarak dengan manusia meskipun dengan menggunakan berbagai macam metode, 50 tidak mungkin di capai oleh manusia. Hermeneutic sebaliknya.

\footnotetext{
48 Adnin Armas, “Westernisasi dan Islamisasi Ilmu” dalam Islamia Tahun II no 6 Juli-September 2005 49 Suharto, "Apakah..

${ }^{50}$ M. Rizka Chamami, Studi Islam Kontemporer, (Semarang : Pustaka Rizki Putra, 2002), 155
} 


\section{Daftar Pustaka}

'Ata al Sid, Muhammad. Sejarah Kalam Tuhan, Jakarta : Teraju PT. Mizan Publika, 2004.

'Imarah. M. "Hadza huwa al Islam: Qiraat al-Nash al Dini baina al Ta'wil al Gharbi wa al-Ta'wil al Islami. Kairo : maktabahal-Syuruq al Dualiyyah, 2006.

Abdullah, Syamsuddin dan harits Abdul Salam dkk, Fenomenologi Agama. Jakarta : tp, 1983-1984.

Aksin Wijaya, Menusantarakan Islam : Menelusuri Jejak Pergumulan Islam yang Tak Kunjung Usai di Nusantara. Ponorogo : STAIN Ponorogo Press, 2011.

al Syibtsari, Muhammad Mujtahid Qiraah Basyariayyah li al-Din, ter. Ahmad al Qbanji, (Beirut : al-Intisyar al Arabi.

Amal, Taufiq Adnan. Rekonstruksi sejarah alQuran. Yogyakarta : FkBA

Arkoun, Muhammad. The Unthought in Contemporary Islamic Thought (London : Saqi Books, 2002

Armas, Admin. “Westernisasi dan Islamisasi Ilmu” dalam Islamia Tahun !! no. 6 JuliSeptember 2005

Bertenz, K. Filsafat Barat abad XX, I Jakarta , Gramedia, 1981.

Bleicher, Josef. Contemporary Hermeneutic (London : Routledge and Paul Keangan, 1980.

Chamami, M. Rizka Studi Islam Kontemporer, Semarang: Pustaka Rizki Putra, 2002.

Hanafi, Hasan. Al Din wa al-Tashwirah fi Mishr, 1952-1981, al Yamin wa al Yasar fi al Fikr al Dini. Kairo : Maktabah madhbuli, 1989.

Hanafi, Hasan. Hermeneutikaal Qurqn, terj. Yudian Wahyudi. Yogyakarta : Nawesea Press, 2009.

Harb, Ali Hermeneutic Kebenaran, Yogyakarta : Lkis, 2003

Hidayat, Komarudin. Memahami Bahasa Agama, Sebuah Kajian Hermeneutik. Jakarta : Paramadina, 1996

Huntington, Samuel. Benturan Antar Peradaban, ter. M. Sadat Ismail Yogyakarta : Bentang, 2000

Ignaz Golziher , Madzahib al Tafsir al Islami. Beirut : Dar Iqra, 1983

Ikhwan, Nur. " al Quran sebagai teks Hermeneutik abu Zaid" dalam Abd Mustaqim (ed), Studi al Quran Kontemporer. Yogya :Tiara Wacana, 2002.

Komer, Felix. Alter Text neur context: Koranhermeneutic in der Turkei heute. Freiburg : herder, 2006)

Kuhn, Thomas S. The structure of Scientific Revolutions : Peran Paradigma dalam Revolusi Sains. Bandung : Remaja Rosdakarya, 2002

Mustaqim, Abdul. Pergeseran Epistemologi Tafsir. Yogyakarta : Pustaka Pelajar, 2008.

Nor, Wan Mohd. The Educational Philosophy and Practice of Syed Muhammad Naquib al-Attas: An Exposition of the Original Concept of Islamization, 1998: 343-344) Lihat, 
artikel Wan Mohd Nor Wan Daud di Majalah Islamia edisi 1, tahun 2004 dan wawancaranya di majalah yang sama pada edisi 2, tahun 2004).

Raharjo, Mudji. "Dasar-dasar Hermeneutika anatar Intensionalisme dan Gadamerian. Yogyakarta : ar-Ruzz Media, 1998

Rahman, Fazlur. Major Themes of The Qur;an. Chicago : Bibliotecha Islamica, 1980

Rahmat, Jalaluddin. Islam dan Pluralisme : Akhlak Qur an menyikapi Perbedaan. Jakarta : Serambi, 2006.

Ritzer, George. Sosiologi Pengetahuan Berparadigma Ganda, ter. Alimandan. Jakarta : Rajawali Press, 2004

Setiawan, Nur kholis. Akar-akar Pemikiran Progresif dalam Kajian al Quran. Yogyakarta : Elsaq, 2008

Suharto, Ugi. “Apakah Al Quran memerlukan Hermeneutika" dalam Islamia, Tahun 1 no.1, 2004.

Verdiansyah, Very. Islam Emansipatoris : Menafsirkan Agama untuk Praksis Pembebasan. Jakarta : P3M, 2004.

Wahyudi, Yudian. Ushul Figh versus Hermeneutika : membaca Islam dari Kanada dan Amerika. Yogyakarta: Pesantren Nawesea Press, 2006

Wijaya, Aksin. Paradigma baru Wacana Agama : Melepaskan Agama dari BayangBayang Lembaga, Organisasi dan Aliran Keagamaan", Millah : Jurnal Studi Agama, Pascasarjana UII, vol 7, no 2 Februari 2008

Zaid, Nasr Hamid. Abu Isykaliyat al ta;wil wa aliyat al Qira;ah, Kairo : al Markaz al Tsaqafi, tt), 11, Sumaryono, Hermeneutic, Yogya, kanisius, 1996. 